Chapter 11

\title{
TRANSFORMATION OF THE RURAL ECONOMY
}

\section{Keijiro Otsuka and Xiaobo Zhang}

The transformation of the rural economy is often accompanied by (1) increasing productivity of staple crop farming, (2) the introduction of more profitable high-value agricultural products, (3) more lucrative employment opportunities in rural nonfarm sectors (World Bank 2007; de Janvry, Sadoulet, and Murgai 2002), and (4) migration. Developing rural industries is a major way to increase employment opportunities in rural nonfarm sectors (Hayami 1998; Haggblade, Hazell, and Reardon 2007; Otsuka 1998, 2007). Although relationships among technological innovations in agriculture and the development of rural nonfarm sectors are highly complex, we attempt to sketch the farm-nonfarm sectoral linkages in the next section.

In low-income economies where land is relatively scarce and labor is abundant, notably in tropical Asia and increasingly in Africa south of the Sahara (SSA), the Green Revolution (the development and diffusion of high-yielding varieties of cereal crops) ought to be a major way to increase the productivity of rice, wheat, maize, and other staple crop farming (Evenson and Gollin 2003). ${ }^{1}$ However, the Green Revolution has not taken place in most areas of SSA, where farm size is now almost as small as that in tropical Asia in the 1960s. It is also unclear to what extent the Green Revolution stimulated the development of nonfarm sectors through growth linkages. Next, we explore why SSA has failed to realize the Green Revolution and the extent to which the Green Revolution stimulated the development of nonfarm sectors in rural areas in tropical Asia.

In developing countries, markets of modern inputs—such as improved seeds, effective chemical fertilizer, and safe pesticides as well as credit markets-do not function well, nor does the market for high-value agricultural products, whose quality and safety cannot be easily identified by visual inspections of consumers. Also the market of production information services

1 In Africa, root crops like cassava and yams have experienced large productivity gains (Haggblade and Hazell 2010). 
ubiquitously malfunctions, not to mention the malfunctioning of publicsector extension systems. Thus contract farming, which provides high-quality inputs on credit and production instruction, is considered to be an effective institutional device to overcome market failures. ${ }^{2}$ Fears, however, are widely expressed that contract farming may primarily benefit large farmers because transaction costs can be saved by making a small number of contracts with large farmers rather than a large number of contracts with smallholder farmers (Otsuka, Nakano, and Takahashi 2016; Ton et al. 2018).

The chapter examines whether contract farming confers benefits primarily to large farmers in practice and how we may be able to make smallholders significantly better off by introducing new profitable crops and livestock products. More often than not, agriculture does not provide ample employment opportunities, largely due to land constraints on production expansion. One solution is to develop nonfarm sectors so as to provide more lucrative employment opportunities, in which working members of farm households increasingly find jobs. The chapter demonstrates the critical importance of increasing nonfarm income to improve the income of rural households and examines the roles of infrastructure and human capital in raising nonfarm income.

In general, the service sector is growing faster than the industrial sector in developing countries. One key driver is remittance sent home by migrants. It has been widely documented that most remittances are spent on housing, land purchase, and local service sectors (Ballard 2001). Broadly speaking, the service sector consists of traditional and modern service jobs. Jobs in traditional service sectors (for example, vending, rickshaw driving, and garbage picking) are low-paying, whereas jobs in modern service sectors (such as ICT-related service providers and finance) are high-paying but are offered only to highly educated workers. In order to provide ample and lucrative employment opportunities to a large, relatively uneducated and unskilled rural labor force, the development of labor-intensive industries in rural areas is indispensable. The chapter identifies the major characteristics of successfully developed rural industries and explores how we can stimulate the development of such industries. We conclude with a discussion of the role of rural-to-urban migration in the transformation of the rural economy and policy implications.

2 This is called the production contract, under which autonomy of farmers is restricted. However, farmers maintain greater autonomy under the market contract, which primarily specifies prices, quantity, and quality of products delivered as well as delivery dates. 


\section{A Conceptual Framework of Farm-Nonfarm Linkages}

Following de Janvry and Sadoulet (2002) and Otsuka, Estudillo, and Sawada (2009), Figure 11.1 illustrates how technological innovations in agriculture, such as the Green Revolution and the introduction of high-value agricultural products, and investment in rural infrastructure affect rural income directly by increasing the efficiency and profitability of farming and indirectly through the growth linkage effects on nonfarm sectors, the inducement effect of improved infrastructure on the development of nonfarm sectors, and the reduction in prices of agricultural products. ${ }^{3}$

Although the growth linkage effects on the development of nonfarm sectors are expected to be positive, a reduction in agricultural prices will have negative effects on farm income. Another major factor that affects the income of rural households and the development of nonfarm sectors is human capital. Schooling, which is a major component of human capital along with health, is known to affect the efficiency of farming (for example, Foster and Rosenzweig 1996) and to have a positive effect on the choice of nonfarm jobs, rural-tourban migration, and nonfarm income (for example, Matsumoto, Kijima, and Yamano 2006; Jolliffe 2004). Furthermore, the supply of an educated labor force to the nonfarm sectors will contribute to their development (Otsuka, Estudillo, and Sawada 2009; Estudillo and Otsuka 2016). The income of a rural household is a major determinant of its investment in human capital (Otsuka, Estudillo, and Sawada 2009). If the Green Revolution or a "highvalue product revolution" takes place, thereby improving farm income and stimulating the development of the nonfarm sectors, there can be a virtuous circle of income growth, increased investment in human capital, and subsequent development of the farm and nonfarm sectors.

So far we have treated the Green Revolution, the introduction of highvalue products, and investment in infrastructure as if they are exogenous, and responses of agricultural product markets, the development of nonfarm sectors, and human capital as partly endogenous and partly exogenous. The success or failure of the Green Revolution critically hinges on government policies, because new improved seeds, particularly if they can be reproduced, are public goods. New knowledge of improved production practices, which can be conveyed by the extension system, is also a local public good. Given

3 For simplicity, Figure 11.1 does not take into account the consumption linkage effect of agricultural innovations on nonfarm sectors that arises from an increase in farm income. Also the possible effect of human capital on the introduction of new agricultural technologies and products is ignored. 
FIGURE 11.1 An illustration of farm-nonfarm sectoral linkages

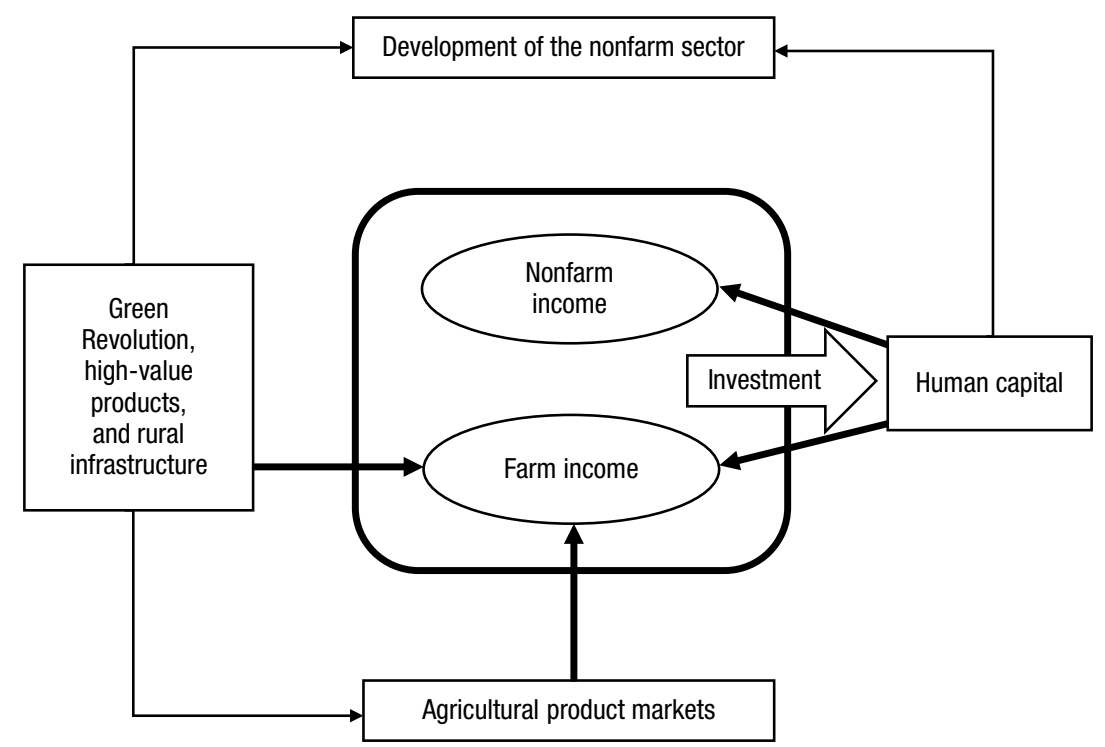

Source: Based on Estudillo and Otsuka (2016, Figure 1.6, p. 18).

inefficiency of public-sector extension systems, the role of social networks or farmer-to-farmer extension has received increasing attention (Takahashi, Muraoka, and Otsuka 2020).

While improved infrastructure may stimulate the development of both the farm and nonfarm sectors, the latter may increase the demand for infrastructure investments (Zhang and Fan 2004; Gibson and Olivia 2010). The introduction of high-value products in developing countries is often driven by rising income, led by the spread of supermarkets in both developing and developed countries, which offer contract farming, and sometimes supported by producer cooperatives (Reardon and Timmer 2012; Chapter 12, this volume). So far as contract farming is designed to overcome market failures, there is room for the government to assist in the introduction of high-value products. If agricultural products are freely traded internationally, the impacts of agricultural innovations on domestic prices of agricultural products will be small or negligible, as agricultural prices are largely determined by global supply and demand forces. However, if agricultural markets are mainly local, the price effect of supply changes could be substantial. The development of rural nonfarm sectors is affected not only by the development of agriculture but also by the linkage with urban/industrial sectors and even foreign companies. This 
chapter considers the causes and consequences of the Green Revolution, the introduction of high-value products, the improvement of rural infrastructure, the development of rural nonfarm sectors, and the role of migration in the transformation of the rural economy.

\section{The Green Revolution and Rural Development}

\section{The Green Revolution}

Although the best indicator of technological change or production efficiency is total factor productivity (Gollin and Udry 2019), an easily available proxy for production efficiency in agriculture in developing countries is physical yield per hectare of cultivated land. ${ }^{4}$ As shown in Figure 11.2, yields of various crops increased substantially in tropical Asia (Southeast and South Asia) over the past half century, whereas yields were largely stagnant in Africa south of the Sahara, except for wheat, which is produced on large farms in temperate zones. Particularly noteworthy are the dramatic yield growth of rice since the mid-1960s, maize since the mid-1990s, and wheat since the mid-1970s. Such yield growth can be attributed to the Green Revolution, which is characterized by the continuous development of improved varieties and their dissemination (for example, Hayami and Otsuka 1994; Chapter 3, this volume). According to Gollin, Hansen, and Wingender (2018), a 10-percentage point increase in adoption of high-yielding varieties (HYVs) increases GDP per capita by about 15 percent, by the direct effect on crop yields, factor adjustment, and structural transformation. Their study also finds that HYV adoption reduced both fertility and mortality.

Major beneficiaries of the Green Revolution are consumers, because an increased supply of grains results in a large decrease in grain prices given price-inelastic demand for grains (Quizon and Binswanger 1986; Evenson and Gollin 2003). ${ }^{5}$ Not only are farmers producers, they are consumers as well. On the one hand, they lose from decrease in grain prices; on the other hand, they gain as consumers. By comparison, urban consumers unambiguously benefited from the decline in grain prices. The gain for consumers can be most clearly seen in the declining real price of rice, primarily grown in Asia,

4 Alternatively, a change in profit is also a good indicator of the impact of new technology (Foster and Rosenzweig 2010). It is, however, practically difficult to measure the cost of unpaid family labor, which plagues the use of profit as the efficiency indicator.

5 Theoretically, aggregate benefits for consumers and producers depend critically on relative elasticities of supply and demand. 
FIGURE 11.2 Average crop yield in tropical Asia and Africa south of the Sahara (tons per hectare), 1961-2018

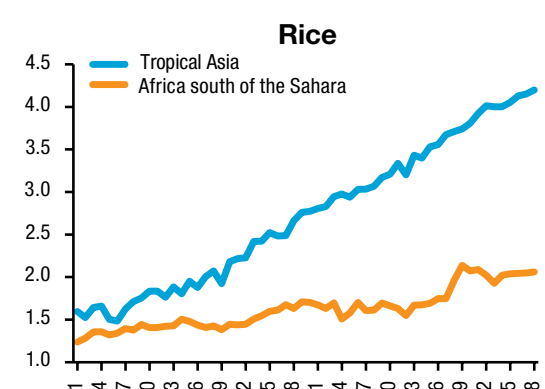

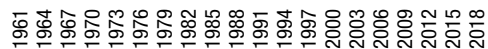
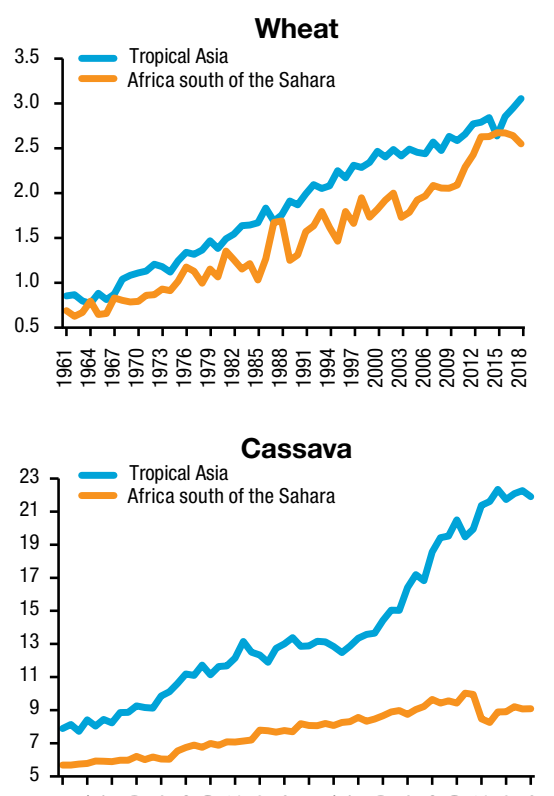

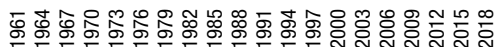

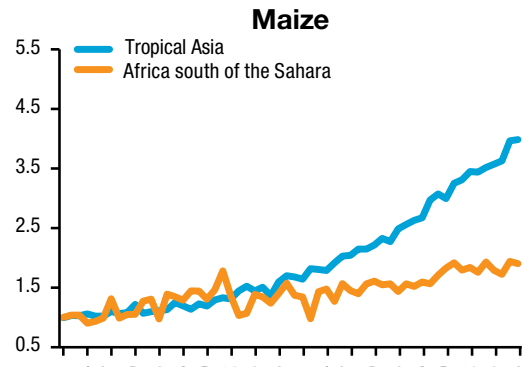

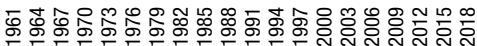
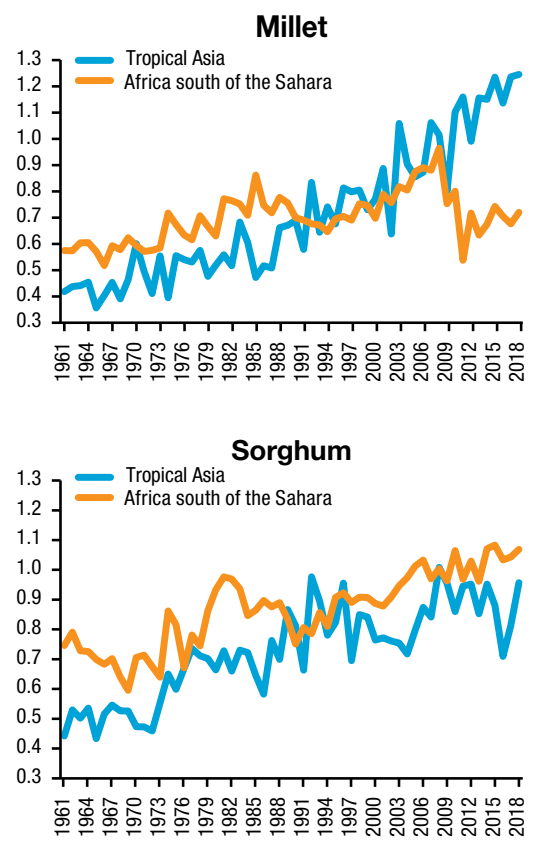

Source: Data from FA0, FAOSTAT various years.

where the Green Revolution has taken place widely (Figure 11.3). Aside from a chaotic hike in rice prices in 1973/1974, the real rice price declined from the late 1960s to the early 2000s, with the lowest price well below one-half of the level around 1970. Even though the productivity of rice farming doubled, rice farmers would not have been made better-off because of the huge price reduction. Since new varieties are high-yielding only in irrigated and favorable 
FIGURE 11.3 World production and real prices of rice, 1960-2015

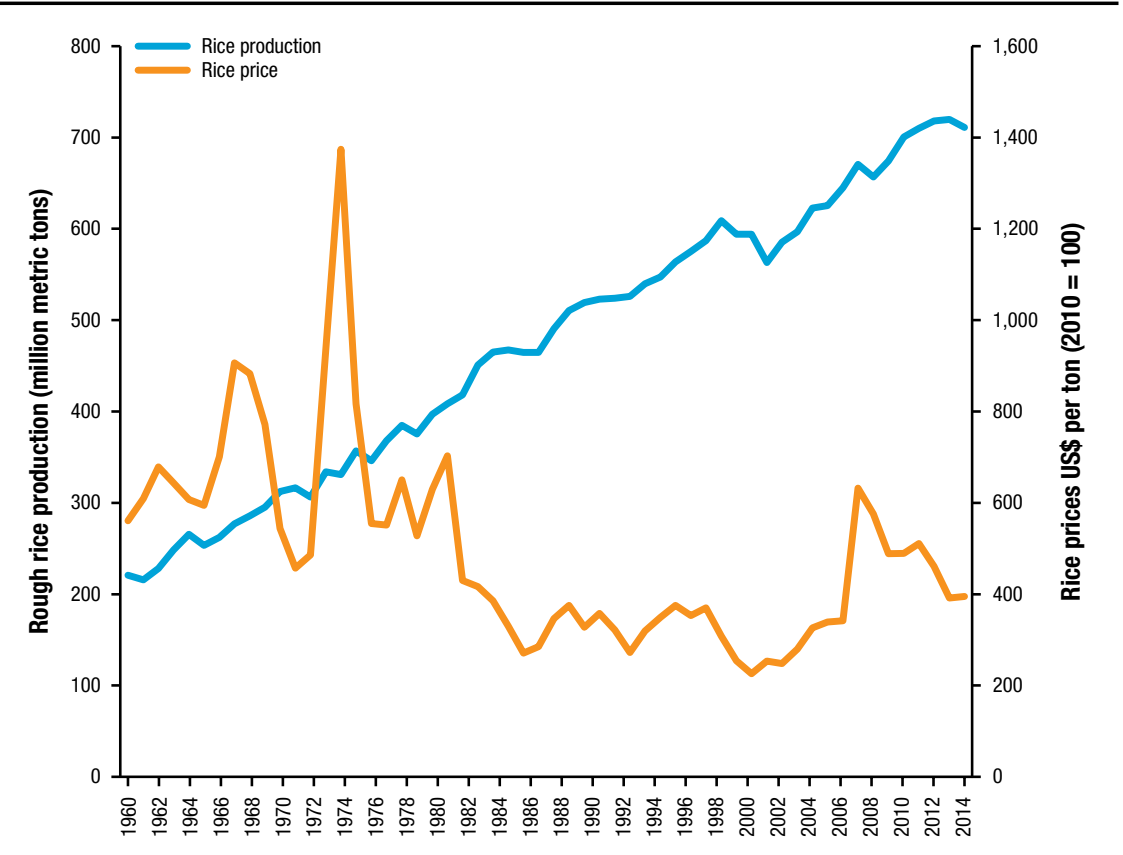

Source: USDA database.

rainfed areas (David and Otsuka 1994), they would have been adopted in 70 percent to 80 percent of the rice area in tropical Asia.

The clear losers are rice farmers who did not have access to improved rice varieties, including those in unfavorable areas subject to flood and drought in Asia and in almost the whole of Africa south of the Sahara. Due to price reductions, these farmers lost not only income but also incentives to grow these crops, whose production increased dramatically in other places. Although not shown in Figure 11.3, real prices of wheat and maize also declined as much as that of rice, due at least in part to the Green Revolution of these crops in Asia. Thus it is possible that one of the reasons for the failure of the Green Revolution in Africa south of the Sahara was the low grain prices that resulted from the successful Green Revolution in Asia.

\section{Growth Linkage Effect}

The agricultural growth linkage hypothesis postulates that modern agricultural technology propels the development of the nonfarm economy through several production and consumption linkages (Haggblade, Hazell, and 
Dorosh 2007). On the production side, improved agricultural technology may spur the birth and development of industries engaged in the production of agricultural inputs (for example, implements) and service-related support to the agriculture sector (for example, repair shops for agricultural machinery and delivery of fertilizer). In addition, an increase in the supply of agricultural products breeds food processing and agro-based manufacturing industries. On the consumption side, increases in rural household income brought about by increased agricultural productivity stimulates consumer demand for locally produced nonfarm goods and services.

A critical assumption of the growth linkage hypothesis is that the increased local demand for nonfarm goods and services leads to the increased local supply of those goods and services. In fact, it is often assumed that supply curves of locally produced goods and services are elastic. Yet in the case of tradable goods, increased local demand may induce increased supply from other locations, such as industrial clusters elsewhere, unless rural areas have capacity to produce what Ranis and Stewart (1993) have called "modern Z-goods." Thus the growth linkage effects are likely to be pronounced in the case of nontradable services, such as retailing of agricultural inputs, milling services, and machine repair services (Haggblade, Hazell, and Dorosh 2007; Renkow 2007), as well as processing in the case of perishable products that must be processed immediately after harvesting.

There is lack of strong econometric evidence that supports the significant effect of agricultural growth on nonfarm sector development (for example, Ramos et al. 2012). Increased local demand for nonfarm goods and services may stimulate an increased supply of these goods and services in the entire economy but not necessarily in the locality where agricultural technological change takes place (Christiaensen, Demery, and Kuhl 2011). For example, the success of rural reform in the 1980s in China stimulated the demand for manufacturing goods, which boosted the subsequent rapid growth of township- and village-owned enterprises and private enterprises nationwide. But the growth is uneven across regions. Most manufacturing activities have been increasingly concentrated in some coastal areas, which are not necessarily the major cropping regions.

Recently Bustos, Caprettini, and Ponticelli (2016) found that the introduction of genetically engineered soybean seeds, a labor-saving agricultural technology, reduced labor demand in agriculture, inducing workers to reallocate toward the local manufacturing sector in Brazil. By contrast, the introduction of maize as a second-season crop increased agricultural labor use. Thus, if regional labor mobility is low, labor-saving technological change 
in agriculture may stimulate industrial development in rural areas, while land-saving technologies may not. In fact, the Green Revolution is largely labor-using, thereby likely not inducing workers to relocate to the local nonfarm sector.

\section{Failure of the Green Revolution in Africa South of the Sahara}

The Asian Green Revolution in rice and wheat began more than a half century ago in the 1960s, when the International Rice Research Institute (IRRI) and the International Maize and Wheat Improvement Center (CIMMYT) released the semi-dwarf, high-yielding modern rice and wheat varieties (MV), respectively (Dalrymple 1978; Hayami and Otsuka 1994; Byerlee and Moya 1993). According to Hayami and Godo (2005: 96-97), "As agriculture is strongly constrained by environmental conditions, it is difficult to transfer advanced technologies developed in the temperate zone to the tropical zone.... IR8 was modeled after the high-yielding Japanese varieties." Although it is understandable that transfer of agricultural technology from the temperate zone to the tropical zone was difficult, it is puzzling why, after 50 years, agricultural technology developed in tropical Asia has not been successfully transferred to SSA, which is also located in the tropical zone.

According to Boserup (1965), population pressure on limited land areas stimulates the adoption of land-saving and labor-using production methods spontaneously by farmers, which leads to an increase in crop yield. Hayami and Ruttan (1985) extend the view of Boserup by arguing that population pressure induces not only technological innovations but also institutional innovations that support the development and diffusion of innovations. Following Schultz (1964), we assume that farmers in poor economies are rational and willing to adopt new technologies if they are profitable. If this is true, the failure of the new agricultural technologies to take hold in SSA could simply have been because they were not yet profitable in the conditions of SSA. Because of rapid population growth in SSA, arable land per capita in rural areas now is nearly comparable with that in Asia in the early 1960s (Figure 11.4). If Boserup's and Hayami-Ruttan's hypotheses are correct, there ought to be the sign of agricultural intensification and yield growth in this continent. A careful look at Figure 11.2 indicates that yield of grains,

6 IR8 was the first MV released by IRRI in 1966, whose parent came from Taiwan. Hsieh and Ruttan (1967) argued that new rice varieties being developed in tropical Asia in the 1960s resembled, in terms of fertilizer responsiveness and yield potential, the ponlai varieties introduced to Taiwan by the Japanese colonial government in the mid-1920s. Also see Hayami and Ruttan (1970). 
FIGURE 11.4 Arable land per rural population in tropical Asia and Africa south of the Sahara, 1961-2016

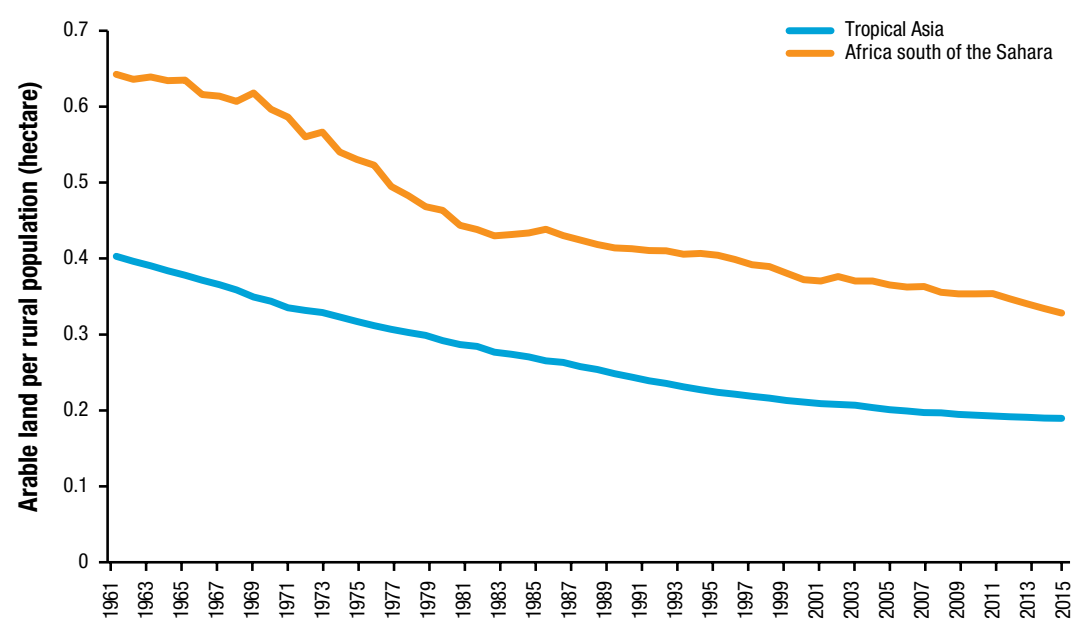

Source: FAO, FAOSTAT.

particularly rice and maize, began growing around the beginning of this century. Whether this is the initial phase of the Green Revolution in SSA is an extremely important open research question.

The first possible reason for the failure of the Green Revolution in Africa south of the Sahara is that agroclimates are so different between tropical Asia and SSA (Evenson and Gollin 2003) and vastly heterogeneous within SSA (Suri 2011), making Asian technology nontransferable. That is, without major changes in the plant, plant performance would be so poor as to be unprofitable in many regions of SSA. The hypothesis of different agroclimates, however, is not necessarily plausible because crop yields before the Green Revolution were comparable between SSA and tropical Asia (see Figure 11.2). Also, as far as rice is concerned, many Asian varieties and their offspring are grown well in SSA by means of adaptive research (Yamano et al. 2016).

Yet heterogeneity of agroclimate can be a serious constraint on new technology adoption, particularly in Africa south of the Sahara, where crop mix is diverse and vastly different in different locations (Otsuka and Larson 2013). Because of the heterogeneity of agroclimate as well as farmers' abilities, the same technology may have different returns for different farmers on different

7 Otsuka and Larson (2013) point out that lowland rice technology is highly transferable from Asia to SSA. 
plots (Foster and Rosenzweig 2010; Suri 2011). ${ }^{8}$ In a study on Kenyan maize farming, Suri (2011) finds that farmers with high net returns adopted hybrid maize seeds, whereas farmers with low net returns did not. She suggests that removing supply and infrastructure constraints would be a cost-effective policy to raise hybrid seed adoption rates. Gollin and Udry (2019) demonstrate that the dispersion of total factor productivity is very high in Uganda and Tanzania even among plots cultivated by the same farmer, indicating large heterogeneity in production environments across plots. In contrast, however, Michler et al. (2019) find that adoption of improved cowpea seeds reduced production cost of a large number of farmers in Ethiopia.

Another possibility is that while scientific research was successful and hence suitable and profitable technologies were available in SSA, the technologies have not been disseminated widely due to lack of an effective extension system. If there were little effort to disseminate such technology, farmers simply would not have been aware that it was available. A failure to recognize that the high-yielding Asian farming practices are management-intensive, at least compared with the existing cultivation methods in SSA, seems to deter the establishment of effective public-sector extension systems. Important crop management activities, or agronomic practices, include using improved seed, seed selection, leveling fields and construction of bunds for water and weed management, row transplanting, and fertilizer application in lowland rice farming, and the application of manure and compost, intercropping with leguminous crops, which have capacity to fix nitrogen from the atmosphere, and mulching, in upland farming. African farmers seldom adopt these practices. Importantly Otsuka and Larson (2016) argue that the failure of the Green Revolution in SSA can be attributed to the lack of recognition that Green Revolution technology is management-intensive and to the absence of an effective public-sector extension system. ${ }^{\text {' }}$

It is well-known that new technological information is transmitted from farmers to farmers (see Conley and Udry [2010] for a recent study). Although

8 Because of the heterogeneity, we cannot assume that because a technology is profitable in one time or place, it is also profitable in another. Foster and Rosenzweig (2010) provide an excellent review of the literature on the assessment of the profitability of new technology.

9 This conflicts with a conventional view that the Green Revolution can be alternatively called the "seed-fertilizer revolution" (Johnston and Cownie 1969), which indicates that if improved seeds and fertilizer use are widely adopted, a Green Revolution automatically takes place. However, Murgai, Ali, and Byerlee (2001) and Ali and Byerlee (2002) find that total factor productivity in Indian and Pakistan Punjab grew faster from the mid-1970s to the mid-1980s, when the adoption of modern wheat and rice varieties was already high, than from the mid-1960s to the mid-1970s, when the adoption increased fast. 
efficiency of a public-sector extension system may be improved by eliciting feedback from farmers about the quality and content of agricultural extension services (Jones and Kondylis 2018), a great deal of attention has been paid to the effectiveness of farmer-to-farmer extension and a number of randomized controlled trials (RCTs) have been conducted. Although Kondylis, Mueller, and Zhu (2017) find that training provided by extension agents to selected contact farmers for technology diffusion to other farmers does not work, BenYishay and Mobarak (2018) find that providing reward to contact farmers, who are ordinary farmers, for their successful technology dissemination leads to wider adoption of new technology. Shikuku et al. (2019), however, find that providing private material reward to contact farmers did not have any impacts, even though reputational gain for them from knowledge diffusion facilitated knowledge dissemination. Takahashi, Mano, and Otsuka (2019) report that a package of improved rice cultivation methods has been diffused from randomly selected training participants to other farmers without any material reward in Côte d'Ivoire. How to select contact farmers and under what conditions new knowledge can be diffused from them to other farmers are critically important yet unexplored issues in technology diffusion..$^{10}$

There are several other possible constraints on new technology adoption, such as inadequate education of farmers for acquiring and decoding new technology information, and the incompleteness of insurance and credit availability for dealing with the production risk associated with the adoption of new technology (Foster and Rosenzweig 2010; Chapters 16 and 17, this volume). It is not clear, however, to what extent such constraints are particularly serious in SSA. According to Chapter 5 in this book, agricultural wage rates tend to be high in SSA, particularly during peak seasons, when labor shortage is acute in predominantly rainfed farming. ${ }^{11}$ As a result, labor-intensive and management-intensive Green Revolution technology may not be highly profitable for farmers even if it boosts higher yield. If high wages are the root cause, mechanization has to be introduced, together with yield-enhancing technology, in order to realize the Green Revolution in Africa south of the Sahara. As a matter of fact, agricultural mechanization has begun to take off in SSA (Diao and Kolavalli 2014). Another possible reason for the failure of the Green Revolution was low grain prices, as was discussed earlier in this chapter.

10 See Takahashi, Muraoka, and Otsuka (2020) for a review of the recent literature on technology adoption and extension.

11 Since the timing of farming depends on the timing of rainfall under rainfed farming, labor demand of all the farmers changes simultaneously. As a result, peak-season labor demand is high relative to supply of labor. 


\section{Development of High-Value Product Sectors}

To introduce high-value agricultural products such as fresh vegetables and fruits and livestock products, a variety of market failures, including the malfunctioning of markets of improved seeds, safe pesticides, and credit, as well as the absence of management service providers, must be dealt with (see Chapter 12 for a discussion of the transformation of food value chains). Furthermore, compared with staple crops, it is more difficult for consumers to identify the quality and safety of high-value products due to larger quality variations (Bai 2016). Thus consumers place more premium on truly high-value agricultural products if their quality and safety are verifiable and traceable or if production standards meet international standards (Ortega et al. 2011; Ifft, Roland-Holst, and Zilberman 2012).

Another problem is the riskiness of high-value products, whose prices fluctuate widely and unexpectedly. Thus sellers who can guarantee the quality and safety of such products to consumers and who can shoulder the price risk by offering a fixed product price (or similar pricing formulae) in advance are indispensable for product markets to work and for farmers to undertake new businesses. ${ }^{12}$ Contract farming offered by large supermarkets and agroprocessors is designed to overcome these market failures (Barrett et al. 2012; Otsuka, Nakano, and Takahashi 2016). ${ }^{13}$ Supermarkets and agro-processors provide inputs on credit and production instruction to farmers and undertake marketing. Once new improved inputs and superior production technologies are introduced, the efficiency of farming of high-value products in developing countries is improved. Thus the World Bank (2007) strongly recommends the introduction of high-value products by contract farming in developing countries.

The transaction cost associated with contract farming may be substantial. If input prices charged by the contractor are lower than market prices, contract farmers have incentive to divert the use of inputs for other purposes. If product prices paid by the contractor are lower than market prices, contract farmers have incentive to sell products at the market rather than deliver them to the contractor as promised (Kunte, Wollni, and Keser 2017). Farmers

12 Michelson, Reardon, and Perez (2012) found that contract farming with Walmart supermarket significantly reduced price risk, even though mean prices paid to farmers are lower than the traditional market in Nicaragua.

13 As Casaburi and Macchiavello (2019) suggest, another advantage of contract farming over ordinary market exchange with traders may be that a farmer prefers to receive payments infrequently (for example, monthly rather than receiving payments every time a transaction is made), because the farmer can commit to saving under infrequent payment. This argument applies to milk and tea production rather than crops harvested infrequently. 
also may not follow the production instructions specified by the contract. Therefore, the contractor will prefer to make a small number of contracts with large farmers, rather than a large number of contracts with smallholders. In this way, smallholder farmers may be excluded from contract farming.

A large number of studies, including recent studies by Mishra et al. (2016), Michelson (2013), and Ragasa, Lambrecht, and Kufoalor (2018) as well as a review article by Ton et al. (2018), found that farmers who are engaged in contract farming are larger landholders or wealthier farmers. According to the literature review by Otsuka, Nakano, and Takahashi (2016), although contract farmers are larger than noncontract farmers in terms of cultivation area, the difference between them is very small, indicating that farm size may not be the decisive factor affecting the choice of contract farmers. In order to make contracts with large buyers, smallholder farmers often establish producer cooperatives, which make contracts with buyers on behalf of small producers. Furthermore, producer cooperatives sometimes undertake market research to find out which products are highly demanded at the markets, introduce new profitable crops and technology for member farmers, negotiate better prices for input purchase, and guarantee the quality and safety of high-value products produced by member farmers to the buyer (Hashino and Otsuka 2016). To the extent that transaction costs among member farmers of producer cooperatives are sufficiently low, the emergence of producer cooperatives will help smallholder farmers participate in contract farming. In a nutshell, smallholder farmers are not always excluded from contract farming in practice. Furthermore, by receiving relevant market and technological information and services from cooperatives, small subsistence farmers may be transformed into profit-oriented farmers.

Another issue is the extent to which farmers are made better off by entering contract farming. The identification of the impact of contract farming on farmers' welfare is not easy, because contracts are endogenously chosen by the firm and farmers (Barrett et al. 2012; Bellemare and Bloem 2018). Because of the difficulty in finding a truly exogenous instrumental variable that is strongly correlated with participation in contract farming, the internal validity, or the ability of a study to identify treatment effects, may be limited (Bellemare and Bloem 2018). Even though Bellemare and Lim (2018) argue that the causality of the welfare impacts of contract farming has thus far been elusive, the available evidence suggests that contract farming increases the welfare of farmer households, as reflected in increased household or crop income (Maertens and Vande Velde 2017), profit (Mishra et al. 2016), community wealth (Gatto et al. 2017), productive assets (Michelson 2013), and subjective 
well-being (Väth, Gobien, and Kirk 2019). While the existing studies rely on observational data, a recent study by Arouna, Michler, and Lokossou (2019) conducted an RCT by offering fixed-price contracts to reduce price uncertainty, fixed-price with management training contracts, and fixed-price with management training and input provision contracts. They find significant and positive impacts of these contracts on rice area, rice yield, proportion of rice sold, and rice income. One difficulty of this study is the focus on rice income, as a measure of welfare effect, because additional family resources may be allocated to rice framing at the sacrifice of nonrice cultivation.

In contrast, Ragasa, Lambrecht, and Kufoalor (2018) and Soullier and Moustier (2018) did not find significant impacts of contract farming on profitability of rice farming. ${ }^{14}$ Ton et al. (2018) point out through meta-analysis that assessment of the income effect of contract farming is upwardly biased due to mechanically excluding contract farming arrangements that failed and due to the tendency that primarily successful cases of contract farming are reported in published articles. Otsuka, Nakano, and Takahashi (2016) also question whether contract farmers, who passively accept inputs and follow the production instructions given by the contractor without making risky decisions under uncertainty, receive significantly higher income. As Schultz has argued (1974), high income accrues to the ability to make proper decisions under a dynamically changing setting. If this is the case, it is likely that contract farmers receive only marginally higher income than alternative income sources. To conclude, it is fair to argue that the effect of contract farming on the welfare of smallholder farmers needs to be explored further in a variety of settings, while carefully dealing with selection bias arising from endogenous choice of contractual arrangements.

By conducting an RCT in collaboration with an NGO, Ashraf, Gin, and Karlan (2009) offered contract farming with provision of services and credit and found certain effects on the production of export crops and income compared with the control group. ${ }^{15}$ Bellemare and Bloem (2018) point out, however, that since nonprofit organizations are involved, the external validity of their study, or the ability to extrapolate their research findings across time and space, will be limited. Bernard et al. (2018) conducted an RCT in which a micronutrient-rich fortified yogurt is additionally provided to contract

14 Among staple crops, the quality variations are larger for rice than others, and rice is sometimes a commercial crop in Africa south of the Sahara.

15 See de Janvry, Sadoulet, and Suri (2017) for an excellent review of the literature for field experiments in agriculture. 
farmers. They found that the provision of nutrient-based incentives had large and significant impacts on the frequency and amount of milk delivered during the dry season, particularly when suppliers are women. Casaburi and Willis (2018) conducted another RCT in which the contractor offers insurance to contract farmers and deducts the premium from farmers' revenues at harvest time. According to this study, delaying the premium payment until harvest results in a large increase in insurance demand. These studies indicate that there is room for further improving the nature of contract farming for the benefit of smallholders.

Otsuka, Nakano, and Takahashi (2016) argue that to make farmers truly better off, farmers must be transformed from ordinary farmers engaged primarily in production to "entrepreneurial" farmers engaged also in market research, production designs, technology and crop choices as well as marketing. If and only if farmers are engaged in such pre-production and post-production activities will the introduction of high-value products in developing countries lead to significant improvements in both efficiency and equity.

\section{The Role of Nonfarm Sectors in Income Generation}

There is no doubt that increasing nonfarm income is a major source of increasing rural household income. According to Haggblade, Hazell, and Reardon (2007), the share of nonfarm income in total income of rural households is 51 percent in Asia, 47 percent in Latin America, and 37 percent in Africa in the early 2000s. These numbers are surprisingly consistent with findings of many case studies. For example, de Janvry and Sadoulet (2001) found that its share was 55 percent in Mexico; Estudillo and Otsuka (1999) found a share of 51 percent in the Philippines; and Matsumoto, Kijima, and Yamano (2006) reported shares of 45 percent in Kenya, 30 percent in Uganda, and 13 percent in Ethiopia. It appears that the nonfarm income share is higher in more developed countries. Indeed, the nonfarm income share has been rising with income growth of the economy. For example, the nonfarm income share increased from 27 percent in 1966 to 51 percent in 1994 in the Philippines (Estudillo and Otsuka 1999), 34 percent in 1988 to 46 percent in 2004 in Bangladesh, and 6 percent in 1987 to 37 percent in Thailand's Central Plain, and 30 percent to 81 percent during the same period in the country's northeast region (Otsuka, Estudillo, and Sawada 2009).

There is consensus in the literature that the increasing nonfarm income share is pro-poor, thereby contributing to the equality of income distribution 
(de Janvry and Sadoulet 2010; de Janvry, Sadoulet, and Zhu 2005; Estudillo and Otsuka 1999, 2016; Hayami and Kikuchi 2000; Lanjouw and Lanjouw 2001; Matsumoto, Kijima, and Yamano 2006; Lanjouw and Murgai 2009; Otsuka, Estudillo, and Sawada 2009). A major reason why nonfarm jobs are pro-poor is that land-poor households-that is, landless and near-landless households that belong to the poorest segment of poor rural society-more actively seek nonfarm jobs than landed households. They rely more on labor income than on other income sources, such as land rental revenue and capital income. In Myanmar the shares of nonfarm income were 9 percent and 32 percent for farmers and landless households, respectively, in 1996, whereas the corresponding shares were 18 percent and 62 percent in 2012 (Estudillo and Otsuka 2016). In the Philippines the income of the landless was roughly one-half that of farmer households in 1985, but the incomes of their children were roughly equalized in 2008, owing to the more active participation of children of the landless in nonfarm jobs (Estudillo and Otsuka 2016).

Studies have also indicated that farm households engaging in nonfarm employment tend to earn higher household incomes and produce agricultural products more efficiently, which likely increase and stabilize food consumption. Nonfarm employment also allows farmers to reduce their vulnerability. Nonfarm activities serve as diversification of household earnings to sustain household income and stabilize consumption over time (Seng 2015). In fact, off-farm income is a risk management strategy, which is used for managing the production and income risk to ensure the stability of the farmer's income (Velandia et al. 2009; Ping et al. 2016). Akhtar et al. (2019) investigate the factors affecting the concurrent use of off-farm income diversification strategy and agricultural credit, which the farmers use to manage the risk in maize production in Pakistan. The authors find that education, livestock number, and the risk-averse nature of the farmers are among factors that encourage income diversification. Needless to say, the impact of nonfarm activities depends on the returns from the nonfarm income generation activities. Scharf and Rahut (2014) found that low-return nonfarm work is associated with lower income inequality, while high-return nonfarm activities seem to be linked with less equal household income distribution.

The accurate evaluation of the economic effects of nonfarm activities on farm households is analytically difficult, especially when using household-level cross-sectional data, due to self-selection bias and endogeneity of job choice. Some studies attempt to reduce these issues using econometric techniques, such as propensity score matching used by Owusu, Awudu, and Seini (2011) and Olugbire et al. (2011), to find positive impact of nonfarm employment on 
household income and food security. The development of the nonfarm sector also affects income distribution through the wage channel. Over time, as the nonfarm sector absorbs and eventually exhausts surplus rural labor, real wages tend to increase. This is the so-called Lewis turning point. The arrival of the Lewis turning point has implications for poverty reduction and agricultural production. As most of the poor rely on labor income, rising real wages mean higher family income for the poor even if they work for the same amount of time as before. After a country reaches the Lewis turning point, for example China, poverty incidence tends to decline and income distribution improves (Zhang et al. 2014; Wang et al. 2016). The pressure of labor shortage after the Lewis turning point also induces farmers to substitute labor for machinery in agricultural production. The rapid spread of agricultural mechanization in China after the arrival of its Lewis turning point is a noted example (Wang et al. 2016; Zhang, Yang, and Reardon 2017).

One of the most important factors affecting the choice of nonfarm jobs and the amount of nonfarm income is schooling (Ackah 2013; Atamanov and Van den Berg 2012; Bezu and Barrett 2012; Cunguara, Langyintuo, and Darnhofer 2011; Do, Nguyen, and Grote 2019; Essers 2016; Marchetta 2013; Nakajima, Otsuka, and Yamano 2017). Although Foster and Rosenzweig (1996) found that schooling affected the profitability of technological change in agriculture in the early phase of the Green Revolution in India, a large number of studies found that schooling affected nonfarm income positively but not farm income (de Janvry and Sadoulet 2010; Estudillo and Otsuka 1999, 2016; Jolliffe 2004; Matsumoto, Kijima, and Yamano 2006; Lanjouw and Murgai 2009; Otsuka, Estudillo, and Sawada 2009). Jolliffe (2004) also demonstrates that schooling positively affects the allocation of time to nonfarm jobs. There is a tendency that the magnitudes of the coefficient of schooling in the nonfarm income regression increase over time (Otsuka, Estudillo, and Sawada 2009; Estudillo and Otsuka 2016). The ownership of land or farm size has a generally negative effect on nonfarm income.

At the same time, increasing rural household income stimulates investment in the schooling of children, who can later find better nonfarm jobs (Otsuka, Estudillo, and Sawada 2009). As illustrated in Figure 11.1, there is therefore a virtuous circle of the development of nonfarm sectors, the increasing income of rural households, the increased investment in the schooling of children, and the supply of an educated young labor force to the nonfarm sectors, which, in turn, contribute to the development of the nonfarm sectors. 
The effects of improved infrastructure, such as improved access to paved roads and a stable supply of electricity, on the development of local nonfarm sectors is not straightforward (see Figure 11.1). For example, road improvement has direct effects on agricultural production and consumption by reducing prices of purchased inputs and consumer goods and increasing agricultural product prices, and indirect effects on the development of farm and nonfarm sectors by inducing investments and institutional changes (Khandker, Bakht, and Koolwal 2009). As pointed out by Renkow (2007), however, infrastructure is a double-edged sword: While adequate roads, improved communication facilities, and a stable supply of electricity will stimulate development of the nonfarm sectors, connecting rural areas to urban areas via infrastructure improvement and expansion will strengthen competition with urban firms. The agglomeration effect in cities may attract more nonfarm jobs to cities. Although investment in rural infrastructure fosters overall economic growth, whether it promotes development of local rural nonfarm sectors is an empirical question.

As would be expected, increased road density and road access have positive impacts on total factor productivity in agriculture in India (Zhang and Fan 2004) and on greater specialization of crops and larger application of fertilizer in China (Qin and Zhang 2016). More important, there are several studies that report the positive effects of improved quality or quantity of rural infrastructure on nonfarm production and share of nonfarm income (Fan and Zhang 2004; Gibson and Olivia 2010; Khandker, Bakht, and Koolwal 2009; Qin and Zhang 2016; Ramos et al. 2012). As pointed out by Ramos et al. (2012), however, the impacts of rural infrastructure on the development of manufacturing sectors in remote rural areas are rarely found.

In contrast, Khandker and Koolwal (2010) find in rural Bangladesh that the expansion of irrigation, paved roads, electricity, and access to formal and informal credit are positively associated with farm and rural nonfarm incomes probably because of high population density. The authors also found that the income gains did not translate to significant poverty reduction for the poorest households. Senadza (2012) noted in a study of Ghana that gender composition of households, age, education, and access to credit, electricity, and markets are among important determinants of nonfarm activities and income. In addition, Demissie and Legesse (2013) found that livelihood assets (livestock holding, size of cultivated land) and livelihood diversifying strategy (crop-based diversification through number of crops grown and harvested) are important factors affecting successful income diversification. 


\section{Strategy for Rural Industrialization}

More often than not, manufacturing industries are clustered, meaning that enterprises producing the same and related products (for example, partsuppliers and assemblers) are located in a small area (Sonobe and Otsuka 2006). Sonobe and Otsuka (2011) find numerous industrial clusters not only in Asia but also in Africa south of the Sahara, some of which are located outside urban areas. Otsuka (1998) reports that many garment and weaving clusters are located in rural areas in Asia. Renkow (2007) points out that small and medium-sized manufacturing enterprises tend to cluster together in remote rural locations. Long and Zhang (2012) find a large number of industrial clusters in China and conclude that "China's industrialization process is largely cluster-based.” Ali, Peerlings, and Zhang (2014) report a large number of industrial clusters in Ethiopia. Galvez-Nogales (2010) reports that a variety of agro-based clusters exist in rural areas in Latin America, Asia, and Africa. There seems to be little exaggeration in arguing that manufacturing and agro-processing industries in developing countries are clustered in general and clustered in rural areas in particular. These clusters are often located in rural towns, which have been remarkably growing (see Chapter 9).

Why are manufacturing industries so often clustered? According to Marshall (1920), there are three advantages of industrial clusters, which may also be termed agglomeration economies or localization economies: (1) ease of division and specialization of labor between enterprises thanks to their proximity, (2) labor pooling or the development of labor markets, and (3) information spillovers. Ruan and Zhang (2009) and Long and Zhang (2011) point out and statistically confirm that fine division of labor in industrial clusters lowers the cost of initial investment, thereby lowering the entry barriers. In this way, capital constraints in developing countries can be lessened. In addition, thanks to the strong social capital embedded in local communities, trade credit is widely used in clusters, greatly reducing the reliance on working capital.

Sonobe and Otsuka (2006) argue that a variety of skilled workers, such as experienced engineers, designers, and traders, are available in industrial clusters, and are conducive to innovations, alternatively called "new combinations." There has also been a growing number of industrial clusters in China, or "Specialized Towns" with a high concentration of firms producing one specific item. Such industrial development has been facilitated to increase agglomeration economies and visibility for increased specialization as well as an expansion of industrial output, innovation, and regional economic growth 
(Barbieri, Tommaso, and Bonnini 2012). To sum up, there are positive externalities among enterprises in industrial clusters, which attract the entry of new enterprises and contribute to the formation of industrial clusters. This implies that the social benefits of the entry of new enterprises and innovations exceed the private benefits. Rural industrial clusters are often agro-based, processing high-value agricultural products (Galvez-Nogales 2010). Agro-processors include not only food processors, such as producers of potato chips, fruit juice, and wine, but also "pack houses," which undertake washing, fumigation, sorting out, grading, packing, branding, and marketing of fresh vegetables and fruits. While geographical proximity between farmers and processors and among processors does not matter much in cluster development, access to markets and transportation infrastructure play key roles (Cavatassi et al. 2011; Chatterjee and Ganesh-Kumar 2016; Geldes et al. 2015). In order to develop such agro-based industrial clusters, linking the clusters with high-value product sectors through contract farming is indispensable.

According to Sonobe and Otsuka $(2006,2011,2014)$, broadly speaking, there are dynamic and stagnant clusters. Although innovations take place in dynamic clusters that lead to the expansion of production and employment, an improvement of product quality, and the enlargement of innovative enterprises with sizable profits, no such innovations take place in stagnant clusters, in which many small enterprises employ similar production methods, produce similar low-quality products, sell such similar products at the same domestic markets, and earn hardly any profit. Producers in stagnant clusters face challenges of carrying out innovations that often require collective action. Similarly, Galvez-Nogales (2010) confirms that there are both dynamic and stagnant agro-processing clusters.

It is extremely important to recognize that the social return to innovation is higher than the private return due to imitation. This strongly suggests that industrial clusters that successfully internalize externalities by collective action can innovate and grow. Indeed, Hashino and Otsuka (2016) and Galvez-Nogales (2010) show that producer cooperatives play a critical role in introducing new technologies, acquiring new market information, and controlling the quality of products produced by member companies within clusters, not only historically in Japan and France but also in postwar Europe and the developing world. Similarly, Ruan and Zhang $(2009,2016)$ find that the reputation of low-quality producers in industrial clusters in Zhejiang province in China was reversed by the collective action of producer cooperatives, which introduced improved production methods, disseminated them to cooperative 
members, and forced those producers who produced low-quality products to exit. It is interesting to note that the activities of producer cooperatives in industrial clusters are so similar to those of producer cooperatives in contract farming. This is not surprising because the issues facing producers of highvalue agricultural products and those of manufactured goods are qualitatively similar (that is, internalization of externalities).

Producer cooperatives as well as local governments played an important role in organizing collective actions and stimulating innovations (Hashino and Otsuka 2016). A spectacular example is provided by Zhang and $\mathrm{Hu}$ (2014), who find that the local government was instrumental in overcoming a series of bottlenecks facing Anding potato cluster, such as developing local seeds, expanding markets, and attracting starch processing plants. The central question of developing rural industrial clusters is how to stimulate the initiation of new businesses and growth of existing ones. Unfortunately, the existing literature does not provide definitive answers to this question. Otsuka $(1998,2007)$ points out that subcontracting between rural and urban enterprises is one of the ways to introduce new production knowledge to rural areas from outside. Sonobe and Otsuka (2006) report that township-village enterprises in China learned technological and managerial knowledge from stateowned enterprises (SOEs) by recruiting workers of SOEs or employing them as advisers. In China, local governments have embedded incentives to develop the local economy, because local officials' promotion hinges upon local economic growth relative to peers. In addition, local governments and the central government share revenues according to a fixed formula. Therefore, local officials are keen in helping figure out solutions, often indigenous, to overcoming the obstacles facing cluster development. However, local governments in many developing countries do not have such incentives. A research question is how to incentivize local governments so that they have embedded interest in fostering local economic development.

Considering that entrepreneurial human capital is missing in developing countries (Bloom et al. 2012; McKenzie and Woodruff 2014), Sonobe and Otsuka (2014) argue that management training of entrepreneurs (owners and managers) is likely to be an appropriate strategy to stimulate the entry of new enterprises and innovations. Several RCTs demonstrated that management training improves the enterprise performance significantly (Bloom et al. 2013; Mano et al. 2012; Higuchi, Mhede, and Sonobe 2019). Sanyang et al. (2016) support such a view in the context of agro-industries in Africa. In areas without any organically formed industrial clusters, governments may use industrial parks to attract new businesses, in addition to training of potential 
entrepreneurs. ${ }^{16}$ While it is often a great challenge to improve the business environment and infrastructure for a country as a whole, it is viable for governments in developing countries to build industrial parks on a smaller scale to take advantage of agglomeration economies. In industrial parks the government can offer potential first movers various kinds of benefits, such as tax breaks and ready-to-move factory buildings (Zhang 2016). It is very important for the government to take exit strategies into account when designing the investment promotion policy as the government cannot afford to subsidize the firms forever. One should also be aware of the enormous challenges of establishing industrial parks from scratch.

\section{Rural-to-Urban Migration}

In many rural areas, nonfarm job opportunities are limited. Under such circumstances, seeking jobs elsewhere becomes an appealing option. Migration can have a profound effect on the local economy in two ways. First, migration can help increase the level of household consumption and reduce its volatility. After a family member migrates out, the number of people eating at home naturally drops, thereby increasing the food available for the remaining family members (Xing et al. 2009; de Brauw and Ambler 2018). There are also improvements in food security and nutritional status associated with remittance from migrants. Remittances can be spent on household consumption and children's education, serving as an important instrument for poverty reduction (Yang 2011; Kikkawa, Matsumoto, and Otsuka 2019).

In Guatemala and El Salvador, stunting prevalence among children under five appears to be lower among migrant-source households (most of which receive remittances) than nonsource households. In Tajikistan migrant-source households have been found to consume more calories, on average, than nonsource households (de Brauw and Ambler 2018). In northwest Bangladesh an NGO program provided migrant laborers money for bus tickets during the hungry seasons, allowing many to become seasonal migrants. This support led to a long-term increase in seasonal migration and an increase in per capita consumption among migrant households (de Brauw and Ambler 2018). However, there is also evidence that remittance has fueled the conspicuous consumption, such as gorgeous housing and gift-giving (Ballard 2001). Thus negative impacts of migration on the well-being of migrants and their households must be noted (Chen, Kosec, and Mueller 2019).

16 In such a case, what industries the government should support is a major question. 
The second way migration can have a profound effect on the local economy is that remittance can also be used for productive investment. For example, Woodruff and Zenteno (2007) find that more than 20 percent of the capital invested in microenterprises in urban Mexico is financed by remittances from the United States. Yang (2008) shows that in the Philippines remittances are spent on children's education and small enterprises. In Guatemala households receiving either internal or international remittances spend more at the margin on two investment goods-education and housing-compared to what they would have spent on these goods without remittances. These findings support the growing view that remittances can help increase the level of investment in human and physical capital in remittance-receiving countries (Adams and Cuecuecha 2010; Kikkawa, Matsumoto, and Otsuka 2019). Similar findings were made in Ghana, where receiving remittances was linked to more investment in education, housing, and health as well as lower likelihood of poverty (Adams and Cuecuecha 2013).

In contrast, some other studies reveal that remittance has little to do with productive investment (de Brauw and Rozelle 2008). In communities heavily dependent on remittances, people tend to reduce their work effort. As a large proportion of remittances is channeled to local service sectors, such as construction, local manufacturing jobs become less competitive compared with service-sector jobs (Acosta, Lartey, and Mandelman 2009). In the Philippines, overseas migration cuts into the domestic labor force and the receipts of remittances further reduces labor supply, resulting in higher wages. While the impact of the higher wages on competitiveness can be mitigated by the increase in labor productivity, potential long-term negative effects, such as limited diversification of the economy, tend to persist (Bayangos and Jansen 2011).

Third, migration facilitates land consolidation and mechanization in rural areas. As a farmer migrates out, he or she either rents out or sells his or her land. Thus farm size tends to go up with the outflow of migrants (Deininger and Jin 2005). Over time, rural-to-urban migration bids up local wages, inducing farmers to use more machinery to substitute for labor, as in East Asia (Chapter 3; Yang et al. 2013; Wang et al. 2016; Zhang, Yang, and Reardon 2017). In the case of China, rural-to-urban migration saw land use transition accompanied by increased nonfarm income. These nonfarm income sources contribute to stimulation of technology adoption for farming to save agricultural labor and to allow earning of more incomes. Together with improved transportation and marketization, agriculture is gradually transformed from subsistence agriculture to commercial agriculture in China (Chen et al. 2014). 
Overall, migration plays a positive role in expanding the scale of agricultural production and facilitating the adoption of agricultural mechanization by smallholder farmers.

\section{Conclusion}

The first step toward the transformation of the rural economy is to improve the productivity of staple crop production by technological change. This is particularly the case in low-income economies, where population pressure on limited land resources leads to an imbalance between food supply and food demand. The Green Revolution is a solution to this food problem (Otsuka 2013). Since the Green Revolution requires research on crop breeding and improved cultivation practices, as well as extension services, both of which are public goods, the role of government is critical in achieving revolutionary improvements in the productivity of staple crops. Investment in the human capital of farmers through agricultural extension is often neglected but must be an integral part of the strategy in realizing the Green Revolution. Since the Green Revolution pushes the production possibility frontier of the entire economy outward, there will be income gains for the economy as a whole, particularly through reallocation of resources, even though the Green Revolution may not directly stimulate local rural industrialization.

Shift of resources from staple food production to production of high-value products is another important strategy to transform the rural economy. The transformation crucially hinges upon increasing demand for high-value products. Cutting trade barriers and improving infrastructure can help lower the transaction cost from farmgate to consumers and increase market size, thereby improving the profit margin of high-value crop producers.

Contract farming is an effective institutional arrangement to organize the production of high-value crops. Yet, to bring about large income gains to smallholder farmers from the production of such products, it is essential for the government or private sector to provide training to transform ordinary farmers producing staple crops to entrepreneurial farmers who carry out not only production of high-value products but also pre-production and post-production activities. Otherwise, the income of farmers from the production of high-value products may not increase significantly, even if the production efficiency of farming improves dramatically. Another option is to encourage producer cooperatives. By joining cooperatives, smallholder farmers gain greater bargaining power when negotiating with buyers and obtain better access to inputs and services. However, organizing cooperatives involves 
coordination cost. Only when the benefits overtake the cost, do the producer cooperatives sustain.

The importance of nonfarm income has been increasing in the developing world. To provide lucrative nonfarm employment opportunities, governments should recognize the importance of indigenous rural industrial clusters and facilitate their growth through various local policies, such as improving access to markets, organizing training, and inspecting product quality. The clusters capitalize the existing strengths embedded in rural communities-that is, strong social trust and abundant labor. The social rate of return to investment in the training of workers and entrepreneurs exceeds the private rate of return, partly because of the turnover of trained workers and partly because of information spillovers from competent entrepreneurs to others. Thus, in many cases the government must support the investment in training on top of the training offered by the private sector, including producer cooperatives. In areas with an absence of any industrial clusters, the government may try to construct industrial parks, offering some incentives to attract promising entrepreneurs in addition to providing training to potential entrepreneurs. However, the odds of success are often much lower than promoting indigenous clusters.

In areas where local job opportunities are limited, migration is another choice. When migrants find better-paid jobs elsewhere, they send home remittances, which boost the consumption level of remaining family members and reduce poverty. As more rural people migrate out, agricultural land rental markets and mechanization service markets often emerge to cope with the resultant labor shortage. A side effect of remittance is that it often results in conspicuous consumption. In short, whether the rural economy is successfully transformed from subsistence farming areas producing primarily staple crops to a rural economy producing high-value agricultural products and diverse industrial goods depends critically on the role of local government as well as the collective action of producers and agro-processors. Policies that help expand markets and address externality problems should be greatly encouraged. 


\section{References}

Ackah, C. 2013. "Nonfarm Employment and Incomes in Rural Ghana." Journal of International Development 25 (3): 325-339.

Acosta, P. A., E. K. K. Lartey, and F. S. Mandelman. 2009. "Remittances and the Dutch Disease." Journal of International Economics 79 (1): 102-116.

Adams, R. H., Jr., and A. Cuecuecha. 2010. "Remittances, Household Expenditure and Investment in Guatemala." World Development 38 (11): 1626-1641.

_.2013. "The Impact of Remittances on Investment and Poverty in Ghana." World Development 50: 24-40.

Akhtar, S., G. Li, A. Nazir, A. Razzaq et al. 2019. "Maize Production under Risk: The Simultaneous Adoption of Off-Farm Income Diversification and Agricultural Credit to Manage Risk." Journal of Integrative Agriculture 18 (2): 460-470.

Ali, M., and D. Byerlee. 2002. "Productivity Growth and Resource Degradation in Pakistan's Punjab: A Decomposition Analysis." Economic Development and Cultural Change 50 (4): 839-863.

Ali, M., J. Peerlings, and X. Zhang. 2014. "Clustering as an Organizational Response to Capital Market Inefficiency: Evidence from Microenterprises in Ethiopia.” Small Business Economics 43 (3): 697-709.

Arouna, A., J. D. Michler, and J. C. Lokossou. 2019. Contract Farming and Rural Transformation: Evidence from a Field Experiment in Benin. NBER Working Paper 25665. Cambridge, MA, US: National Bureau of Economic Research (NBER).

Ashraf, N., X. Gin, and D. Karlan. 2009. "Finding Missing Markets (and a Disturbing Epilogue): Evidence from an Export Crop Adoption and Marketing Intervention in Kenya." American Journal of Agricultural Economics 91 (4): 973-990.

Atamanov, A., and M. Van den Berg. 2012. "Participation and Returns in Rural Nonfarm Activities: Evidence from the Kyrgyz Republic.” Agricultural Economics 43 (4): 459-471.

Bai, J. 2016. "Melons as Lemons: Asymmetric Information, Consumer Learning and Seller Reputation.” Job Market Paper, Department of Economics, Massachusetts Institute of Technology.

Ballard, R. 2001. "The Impact of Kinship on the Economic Dynamics of Transnational Networks: Reflections on Some South Asian Developments." Centre for Applied South Asian Studies, University of Manchester, UK.

Barbieri, E., M. R. Di Tommaso, and S. Bonnini. 2012. "Industrial Development Policies and Performances in Southern China: Beyond the Specialised Industrial Cluster Program.” China Economic Review 23 (3): 613-625. 
Barrett, C. B., M. E. Bachke, M. F. Bellemare, H. C. Michelson, S. Narayanan, and T. F. Walker. 2012. "Smallholder Participation in Contract Farming: Comparative Evidence from Five Countries." World Development 40 (4): 715-730.

Bayangos, V., and K. Jansen. 2011. "Remittances and Competitiveness: The Case of the Philippines." World Development 39 (10): 1834-1846.

Bellemare, M. F., and J. R. Bloem. 2018. "Does Contract Farming Improve Welfare? A Review.” World Development 112: 259-271.

Bellemare, M. F., and S. Lim. 2018. “In All Shapes and Colors: Varieties of Contract Farming.” Applied Economic Perspectives and Policy 40 (3): 379-401.

BenYishay, A., and M. A. Mobarak. 2018. "Social Learning and Incentives for Experimentation and Communication.” Review of Economic Studies 86: 976-1009.

Bernard, T., M. Hidrobo, A. Le Port, and R. Rawat. 2018. "Nutrition-Based Incentives in Dairy Contract Farming in Northern Senegal." American Journal of Agricultural Economics 101 (2): $404-435$.

Bezu, S., and C. Barrett. 2012. "Employment Dynamics in the Rural Nonfarm Sector in Ethiopia: Do the Poor Have Time on Their Side?" Journal of Development Studies 48 (9): 1223-1240.

Bloom, N., B. Eifert, D. McKenzie, A. Mahajan, and J. Roberts. 2013. “Does Management Matter? Evidence from India.” Quarterly Journal of Economics 128 (1): 1-51.

Bloom, N., C. Genakos, R. Sadun, and J. Van Reenen. 2012. "Management Practices across Firms and Countries." Academy of Management Perspectives 26 (1): 12-33.

Boserup, E. 1965. The Conditions of Agricultural Growth: The Economics of Agrarian Change under Population Pressure. London: George Allen and Unwin.

Bustos, P., B. Caprettini, and J. Ponticelli. 2016. "Agricultural Productivity and Structural Transformation: Evidence from Brazil.” American Economic Review 106 (6): 1320-1365.

Byerlee, D., and P. Moya. 1993. Impacts of International Wheat Breeding Research in the Developing World, 1966-1990. Mexico, DF: International Maize and Wheat Improvement Center.

Casaburi, L., and R. Macchiavello. 2019. "Demand and Supply of Infrequent Payment as a Commitment Device: Evidence from Kenya.” American Economic Review 109 (2): 523-555.

Casaburi, L., and J. Willis. 2018. “Time versus State in Insurance: Experimental Evidence from Contract Farming in Kenya." American Economic Review 108 (2): 3778-3813.

Cavatassi, R., M. Gonzales-Flores, P. Winters, J. Andrade-Piedra, P. Espinosa, and G. Thiele. 2011. "Linking Smallholders to the New Agricultural Economy: The Case of the Plataformas de Concertacion in Ecuador." Journal of Development Studies 4710: 1545-1573.

Chatterjee, T., and A. Ganesh-Kumar. 2016. "Geographical Neighborhood and Cluster Formation: Evidence from Indian Agriculture." Journal of Development Studies 52 (11): 1577-1592. 
Chen, J., K. Kosec, and V. Mueller. 2019. "Moving to Despair? Migration and Well-Being in Pakistan." World Development 113: 186-203.

Chen, R., C. Ye, Y. Cai, X. Xing, and Q. Chen. 2014. "The Impact of Rural Out-Migration on Land Use Transition in China: Past, Present and Trend." Land Use Policy 40: 101-110.

Christiaensen, L., L. Demery, and J. Kuhl. 2011. “The (Evolving) Role of Agriculture in Poverty Reduction: An Empirical Perspective." Journal of Development Economics 96 (2): 239-254.

Conley, T. G., and C. R. Udry. 2010. "Learning about a New Technology: Pineapple in Ghana.” American Economic Review 100 (1): 35-69.

Cunguara, B., A. Langyintuo, and I. Darnhofer. 2011. "The Role of Nonfarm Income in Coping with the Effects of Drought in Southern Mozambique." Agricultural Economics 42 (6): 701-713.

Dalrymple, D. G. 1978. Development and Spread of High Yielding Varieties of Wheat and Rice in the Less Developed Nations. USDA Foreign Agricultural Economics Report 95. Washington, DC: United States Department of Agriculture.

David, C. C., and K. Otsuka, eds. 1994. Modern Rice Technology and Income Distribution in Asia. Boulder, CO: Lynne Rienner.

de Brauw, A., and K. Ambler. 2018. “Tightening Borders and Threats to Food Security." In 2018 Global Food Policy Report, 38-45. Washington, DC: International Food Policy Research Institute (IFPRI).

de Brauw, A., and S. Rozelle. 2008. "Migration and Household Investment in Rural China." China Economic Review 19 (2): 320-335.

Deininger, K., and S. Jin. 2005. "The Potential of Land Rental Markets in the Process of Economic Development: Evidence from China." Journal of Development Economics 78 (1): 241-270.

de Janvry, A., and E. Sadoulet. 2001. "Income Strategies among Rural Households in Mexico." World Development 29 (3): 467-480.

—.2002. "World Poverty and Role of Agricultural Technology: Direct and Indirect Effects." Journal of Development Studies 38 (4): 1-26.

- 2010. "Agricultural Growth and Poverty Reduction: Additional Evidence." World Bank Research Observer 25(1): 1-20.

de Janvry, A., E. Sadoulet, and R. Murgai. 2002. "Rural Development and Rural Policy." In Handbook of Agricultural Economics: Volume 2A, edited by B. L. Gardner and G. C. Rausser, 1593-1658. Amsterdam: North-Holland.

de Janvry, A., E. Sadoulet, and T. Suri. 2017. “Field Experiments in Developing Country Agriculture." In Economic Field Experiments: Volume 2, edited by A. V. Banerjee and E. Duflo, 427-466. Amsterdam: Elsevier. 
de Janvry, A., E. Sadoulet, and N. Zhu. 2005. The Role of Non-Farm Incomes in Reducing Rural Poverty and Inequality in China. CUDARE Working Paper 1001. Berkeley, US: UC Berkeley Department of Agricultural and Resource Economics.

Demissie, A., and B. Legesse. 2013. "Determinants of Income Diversification among Rural Households: The Case of Smallholder Farmers in Fedis District, Eastern Hararghe Zone, Ethiopia." Journal of Development and Agricultural Economics 5 (3): 120-128.

Diao, X., and S. Kolavalli. 2014. "Mechanization in Ghana: Emerging Demand, and the Search for Alternative Supply Models." Food Policy 48: 168-181.

Do, T. L., T. T. Nguyen, and U. Grote. 2019. "Nonfarm Employment and Household Food Security: Evidence from Panel Data for Rural Cambodia.” Food Security: 1-16.

Essers, D. 2016. "South African Labour Market Transitions since the Global Financial and Economic Crisis: Evidence from Two Longitudinal Datasets." Journal of African Economies 26 (2): 192-222.

Estudillo, J. P., and K. Otsuka. 1999. "Green Revolution, Human Capital, and Off-Farm Employment: Changing Sources of Income among Farm Households in Central Luzon, 1966-94." Economic Development and Cultural Change 47 (3): 497-523.

- 2016. Moving out of Poverty: An Inquiry into Inclusive Growth in Asia. London: Routledge. Evenson, R. E., and D. Gollin, eds. 2003. Crop Variety Improvement and Its Effect on Productivity: The Impact of International Agricultural Research. Wallingford, UK: CABI Publishing.

Fan, S., and X. Zhang. 2004. "Infrastructure and Regional Economic Development in Rural China." China Economic Review 15 (2): 203-214.

FAO (Food and Agriculture Organization of the United Nations). FAOSTAT, various years. http://www.fao.org/faostat/en/

Foster, A. D., and M. R. Rosenzweig. 1996. “Technical Change and Human Capital Returns and Investment: Evidence from the Green Revolution." American Economic Review 86 (4): 931-953.

- 2010. "Microeconomics of Technology Adoption." Annual Review of Economics 2 (1): 395-424.

Galvez-Nogales, E. 2010. Agro-Based Clusters in Developing Countries: Staying Competitive in a Globalized Economy. Agricultural Management, Marketing and Finance Occasional Paper 25. Rome: FAO.

Gatto, M., M. Wollni, R. Asnawi, and M. Qaim. 2017. "Oil Palm Boom, Contract Farming, and Rural Economic Development: Village-Level Evidence from Indonesia.” World Development 95: $127-140$. 
Geldes, C., C. Felzensztein, E. Turkina, and A. Durand. 2015. "How Does Proximity Affect Interfirm Marketing Cooperation? A Study of Agribusiness Cluster." Journal of Business Research 68 (2): 263-272.

Gibson, J., and S. Olivia. 2010. “The Effects of Infrastructure Access and Quality on Nonfarm Enterprises in Rural Indonesia." World Development 68 (5): 717-726.

Gollin, D., C. W. Hansen, and A. Wingender. 2018. Two Blades of Grass: The Impact of the Green Revolution. NBER Working Paper 24744. Cambridge, MA: NBER.

Gollin, D., and C. R. Udry. 2019. Heterogeneity, Measurement Error and Misallocation: Evidence from African Agriculture. NBER Working Paper 25440. Cambridge, MA: NBER.

Haggblade, S., and P. Hazell. 2010. Successes in African Agriculture: Lessons for the Future. Baltimore: Johns Hopkins University Press.

Haggblade, S., P. Hazell, and P. Dorosh. 2007. "Sectoral Growth Linkages between Agriculture and the Rural Nonfarm Economy." In Transforming the Rural Nonfarm Economy, edited by S. Haggblade, P. Hazell, and T. Reardon, 141-182. Baltimore: Johns Hopkins University Press.

Haggblade, S., P. Hazell, and T. Reardon, eds. 2007. Transforming the Rural Nonfarm Economy. Baltimore: Johns Hopkins University Press.

Hashino, T., and K. Otsuka, eds. 2016. Industrial Districts in History and the Developing World. Dordrecht, Netherlands: Springer.

Hayami, Y., ed. 1998. Towards the Rural-Based Development of Commerce and Industry. Washington, DC: World Bank.

Hayami, Y., and Y. Godo. 2005. Development Economics: From the Poverty to the Wealth of Nations. New York: Oxford University Press.

Hayami, Y., and M. Kikuchi. 2000. A Rice Village Saga: Three Decades of Green Revolution in the Philippines. London: Macmillan Press.

Hayami, Y., and K. Otsuka. 1994. "Beyond the Green Revolution: Agricultural Development Strategy into the New Century." In Agricultural Technology: Policy Issues for the International Community, edited by J. Anderson, 15-42. Wallingford, UK: CAB International.

Hayami, Y., and V. W. Ruttan. 1970. "Korean Rice, Taiwan Rice, and Japanese Agricultural Stagnation: An Economic Consequence of Colonialism." Quarterly Journal of Economics 84 (4): 562-589.

- 1985. Agricultural Development: An International Perspective. Baltimore: Johns Hopkins University Press.

Higuchi, Y., E. P. Mhede, and T. Sonobe. 2019. "Short- and Medium-Run Impacts of Management Training: An Experiment in Tanzania." World Development 114: 220-236. 
Hsieh, S.-C., and V. W. Ruttan. 1967. "Environmental, Technological, and Institutional Factors in the Growth of Rice Production: Philippines, Thailand, and Taiwan." Food Research Institute Studies 7 (3): 307-341.

Ifft, J., D. Roland-Holst, and D. Zilberman. 2012. "Consumer Valuation of Safety-Labeled FreeRange Chicken: Results of a Field Experiment in Hanoi." Agricultural Economics 43 (6): 607-620.

Johnston, B. F., and J. Cownie. 1969. “The Seed-Fertilizer Revolution and Labor Force Absorption.” American Economic Review 59 (4): 569-582.

Jolliffe, D. 2004. “The Impact of Education in Rural Ghana: Examining Household Labor Allocation and Returns on and off Farm." Journal of Development Economics 73 (1): 287-314.

Jones, M., and F. Kondylis. 2018. “Does Feedback Matter? Evidence from Agricultural Services.” Journal of Development Economics 131: 289-241.

Khandker, S. R., Z. Bakht, and G. B. Koolwal. 2009. “The Poverty Impact of Rural Roads.” Economic Development and Cultural Change 57 (4): 685-722.

Khandker, S. R., and G. B. Koolwal. 2010. "How Infrastructure and Financial Institutions Affect Rural Income and Poverty: Evidence from Bangladesh.” Journal of Development Studies 46 (6): 1109-1137.

Kikkawa, A., T. Matsumoto, and K. Otsuka. 2019. "An Inquiry into the Heterogeneous Outcomes of International Migration: Evidence from Rural Households in Bangladesh." Journal of Development Studies 55 (10): 2106-2128.

Kondylis, F., V. Mueller, and J. Zhu. 2017. "Seeing Is Believing? Evidence from an Extension Network Experiment.” Journal of Development Economics 125: 148-169.

Kunte, S., M. Wollni, and C. Keser. 2017. "Making It Personal: Breach and Private Ordering in a Contract Farming Experiment." European Review of Agricultural Economics 44 (1): 121-148.

Lanjouw, J. O., and P. Lanjouw. 2001. "The Rural Nonfarm Sector: Issues and Evidence from Developing Countries." Agricultural Economics 26 (1): 1-23.

Lanjouw, P., and R. Murgai. 2009. "Poverty Decline, Agricultural Wages, and Nonfarm Employment in Rural India: 1983-2004.” Agricultural Economics 40 (2): 243-263.

Long, C., and X. Zhang. 2011. "Cluster-Based Industrialization in China: Finance and Performance.” Journal of International Economics 84 (1): 112-123.

- 2012. "Patterns of China’s Industrialization: Concentration, Specialization, and Clustering." China Economic Review 23 (3): 593-612.

Maertens, M., and K. Vande Velde. 2017. "Contract-Farming in Staple Food Chains: The Case of Rice in Benin.” World Development 65: 73-87. 
Mano, Y., A. Iddrisu, Y. Yoshino, and T. Sonobe. 2012. "How Can Micro and Small Enterprises in Sub-Saharan Africa Become More Productive? The Impacts of Experimental Basic Managerial Training." World Development 40 (3): 458-468.

Marchetta, F. 2013. "Migration and Nonfarm Activities as Income Diversification Strategies: The Case of Northern Ghana." Canadian Journal of Development Studies 34 (1): 1-21.

Marshall, A. 1920. Principles of Economics. London: Macmillan.

Matsumoto, T., Y. Kijima, and T. Yamano. 2006. "The Role of Local Nonfarm Activities and Migration in Reducing Poverty: Evidence from Ethiopia, Kenya, and Uganda." Agricultural Economics 35 (S3): 449-458.

McKenzie, D., and C. Woodruff. 2014. "What Are We Learning from Business Training Evaluations around the Developing World?” World Bank Research Observer 29 (1): 48-82.

Michelson, H. 2013. "Small Farmers, NGOs, and a Walmart World: Welfare Effects of Supermarkets Operating in Nicaragua." American Journal of Agricultural Economics 95 (3): 628-649.

Michelson, H., T. Reardon, and F. Perez. 2012. "Small Farmers and Big Retail: Trade-offs of Supplying Supermarkets in Nicaragua." World Development 40 (2): 342-354.

Michler, J. D., E. Jiernström, S. Verkaart, and K. Mausch. 2019. "Money Matters: The Role of Yields and Profits in Agricultural Technology Adoption." American Journal of Agricultural Economics 101 (3): 710-731.

Mishra, A. K., A. Kumar, P. K. Joshi, and A. D’Souza. 2016. "Impact of Contracts in High Yielding Varieties Seed Production on Profits and Yield: The Case of Nepal." Food Policy 62: 110-121.

Murgai, R., M. Ali, and D. Byerlee. 2001. "Productivity Growth and Sustainability in Post-Green Revolution Agriculture: The Case of the Indian and Pakistan Punjab." World Bank Research Observer 16 (2): 199-218.

Nakajima, M., K. Otsuka, and T. Yamano. 2017. "Jobs off the Farm: Wealth, Human Capital, and Social Group in Rural Eastern India." Journal of Development Studies 54 (1): 111-132.

Olugbire, O. O., A. O. Falusi, A. I. Adeoti, A. S. Oyekale, and O. A. Adeniran. 2011. "Non-Farm Income Diversification and Poverty Reduction in Nigeria: A Propensity-Score Matching Analysis." Continental Journal of Agricultural Science 5 (3): 21-28.

Ortega, D. L., H. Wang, L. Wu, and N. J. Olynk. 2011. “Modeling Heterogeneity in Consumer Preferences for Select Food Safety Attributes in China." Food Policy 36 (2): 318-324.

Otsuka, K. 1998. "Rural Industrialization in East Asia." In The Institutional Foundations of East Asian Economic Development, edited by Y. Hayami and M. Aoki, 447-475. London: Macmillan. 
. 2007. "Rural Industrialization in East Asia: Its Influences, Nature and Implications." In Transforming the Rural Nonfarm Economy, edited by S. Haggblade, P. Hazell, and T. Reardon, 216-233 Baltimore: Johns Hopkins University Press.

- 2013. "Food Insecurity, Income Inequality, and the Changing Comparative Advantage in World Agriculture." Agricultural Economics 44 (S1): 7-18.

Otsuka, K., J. P. Estudillo, and Y. Sawada, eds. 2009. Rural Poverty and Income Dynamics in Asia and Africa. London: Routledge.

Otsuka, K., and D. Larson, eds. 2013. An African Green Revolution: Finding Ways to Boost Productivity on Small Farms. Dordrecht, Netherlands: Springer.

- 2016. In Pursuit of an African Green Revolution: Views from Rice and Maize Farmers' Fields. Dordrecht, Netherlands: Springer.

Otsuka, K., Y. Nakano, and K. Takahashi. 2016. "Contract Farming in Developed and Developing Countries.” Annual Review of Resource Economics 8: 353-376.

Owusu, V., A. Awudu, and A.-R. Seini. 2011. "Non-Farm Work and Food Security among Farm Households in Northern Ghana." Food Policy 36 (2): 108-118.

Ping, Q., M. A. Iqbal, M. Abid, U. I. Ahmed, A. Nazir, and A. Rehman. 2016. “Adoption of Off-Farm Diversification Income Sources in Managing Agricultural Risks among Cotton Farmers in Punjab Pakistan." Journal of Applied Environment and Biological Sciences 6 (8): $47-53$.

Qin, Y., and X. Zhang. 2016. “The Road to Specialization in Agricultural Production: Evidence from Rural China." World Development 77: 1-16.

Quizon, J., and H. P. Binswanger. 1986. "Modeling the Impact of Agricultural Growth and Government Policy on Income Distribution in India." World Bank Economic Review 1 (1): 103-148.

Ragasa, C., I. Lambrecht, and D. Kufoalor. 2018. "Limitations of Contract Farming as a Pro-Poor Strategy: The Case of Maize Outgrower Schemes in Upper West Ghana." World Development 102: 30-56.

Ramos, C., J. P. Estudillo, Y. Sawada, and K. Otsuka. 2012. “Transformation of the Rural Economy in the Philippines, 1988-2006.” Journal of Development Studies 48 (11): 1629-1648.

Ranis, G., and F. Stewart. 1993. "Rural Nonagricultural Activities in Development: Theory and Application." Journal of Development Economics 40 (1): 75-101.

Reardon, T., and P. Timmer. 2012. "The Economics of Food System Revolution." Annual Review of Resource Economics 4: 225-264. 
Renkow, M. 2007. “Cities, Towns, and Rural Nonfarm Economy.” In Transforming the Rural Nonfarm Economy, edited by S. Haggblade, P. Hazell, and T. Reardon, 183-198. Baltimore: Johns Hopkins University Press.

Ruan, J., and X. Zhang. 2009. "Finance and Cluster-Based Industrial Development in China.” Economic Development and Cultural Change 58 (1): 143-164.

_. 2016. "Low-Quality Crisis and Quality Improvement: The Case of Industrial Clusters in Zhejiang Province." In Industrial Districts in History and the Developing World, edited by T. Hashino and K. Otsuka, 169-189. Dordrecht, Netherlands: Springer.

Sanyang, S., S. J. B. Taonda, J. Kuiseu, N. T. Coulibaly, and L. Konate. 2016. "A Paradigm Shift in African Agricultural Research for Development: The Role of Innovation Platforms." International Journal of Agricultural Sustainability 14 (2): 187-213.

Scharf, M. M., and D. B. Rahut. 2014. "Nonfarm Employment and Rural Welfare: Evidence from Himalaya." American Journal of Agricultural Economics 96 (4): 1183-1197.

Schultz, T. W. 1964. Transforming Traditional Agriculture. New Haven, CT: Yale University Press.

- 1974. "The Value of the Ability to Deal with Disequilibria." Journal of Economic Literature 13 (3): 827-846.

Senadza, B. 2012. "Non-Farm Income Diversification in Rural Ghana: Patterns and Determinants." African Development Review 24: 233-244.

Seng, K. 2015. “The Effects of Nonfarm Activities on Farm Households' Food Consumption in Rural Cambodia." Development Studies Research 2 (1): 77-89.

Shikuku, K. M., J. Pieters, E. Bulte, and P. Läderach. 2019. "Incentives and the Diffusion of Agricultural Knowledge: Experimental Evidence from Northern Uganda.” American Journal of Agricultural Economics 101 (4): 1164-1180.

Sonobe, T., and K. Otsuka. 2006. Cluster-Based Industrial Development: An East Asian Model. Hampshire, UK: Palgrave Macmillan.

-2011. Cluster-Based Industrial Development: A Comparative Study of Asia and Africa. Hampshire, UK: Palgrave Macmillan.

- 2014. Cluster-Based Industrial Developments: Kaizen Management for MSE Growth in Developing Countries. Hampshire, UK: Palgrave Macmillan.

Soullier, G., and P. Moustier. 2018. "Impacts of Contract Farming in Domestic Grain Chains on Farmer Income and Food Security: Contrasted Evidence from Senegal." Food Policy 79: 179-198.

Suri, T. 2011. "Selection and Comparative Advantage in Technology Adoption." Econometrica 79 (1): 159-209. 
Takahashi, K., Y. Mano, and K. Otsuka. 2019. "Learning from Experts and Peer Farmers about Rice Production: Experimental Evidence from Cote d'Ivoire." World Development 122: $157-169$.

Takahashi, K., R. Muraoka, and K. Otsuka. 2020. “Technology Adoption, Impact, and Extension in Developing Countries' Agriculture: A Review of the Recent Literature." Agricultural Economics 51 (1): 31-45.

Ton, G., W. Vellema, S. Desiere, S. Weitushat, and M. D’Haese. 2018. “Contract Farming for Improving Smallholder Incomes: What Can We Learn from Effectiveness Studies?” World Development 104: 46-64.

USDA (United States Department of Agriculture). National Agricultural Statistics Service. Database. www.nass.usda.gov/.

Väth, S., S. Gobien, and M. Kirk. 2019. "Socio-Economic Well-Being, Contract Farming and Property Rights: Evidence from Ghana." Land Use Policy 81: 878-888.

Velandia, M., R. M. Rejesus, T. O. Knight, and B. J. Sherrick. 2009. “Factors Affecting Farmers' Utilization of Agricultural Risk Management Tools: The Case of Crop Insurance, Forward Contracting, and Spreading Sales." Journal of Agricultural and Applied Economics 41: $107-123$.

Wang, X., Y. Futoshi, K. Otsuka, and J. Huang. 2016. "Wage Growth, Landholding, and Mechanization in Chinese Agriculture." World Development 86: 30-45.

Woodruff, C., and R. Zenteno. 2007. "Migrant Networks and Microenterprises in Mexico." Journal of Development Economics 82 (2): 509-528.

World Bank. 2007. World Development Report 2008: Agriculture for Development. Washington, DC: World Bank.

Xing, L., S. Fan, X. Luo, and X. Zhang. 2009. "Community Poverty and Inequality in Western China: A Tale of Three Villages in Guizhou Province.” China Economic Review 20 (2): $338-349$.

Yamano, T., A. Arouna, R. A. Labarta, Z. M. Huelgas, and S. Mohanty. 2016. “Adoption and Impacts of International Rice Research Technologies." Global Food Security 8: 1-8.

Yang, D. 2008. "International Migration, Remittances, and Household Investment: Evidence from Philippine Migrants' Exchange Rate Shocks." Economic Journal 118 (528): 591-630.

_. 2011. “Migrant Remittances.” Journal of Economic Perspectives 25 (3): 129-152.

Yang, J., Z. Huang, X. Zhang, and T. Reardon. 2013. "The Rapid Rise of Cross-Regional Agricultural Mechanization Services in China." American Journal of Agricultural Economics 95 (5): 1245-1251. 
Zhang, X. 2016. Building Effective Clusters and Industrial Parks. IFPRI Discussion Paper 1590. Washington, DC: IFPRI.

Zhang, X., and S. Fan. 2004. "How Productive Is Infrastructure? A New Approach and Evidence from Rural India." American Journal of Agricultural Economics 86 (2): 492-501.

Zhang, X., and D. Hu. 2014. "Overcoming Successive Bottlenecks: The Evolution of a Potato Cluster in China." World Development 63: 102-112.

Zhang, X., S. Rashid, K. Ahmad, and A. Ahmed. 2014. "Escalation of Real Wages in Bangladesh: Is It the Beginning of Structural Transformation?” World Development 64: 273-285.

Zhang, X., J. Yang, and T. Reardon. 2017. "Mechanization Outsourcing Clusters and Division of Labor in Chinese Agriculture." China Economic Review 43: 184-195. 
